\title{
Primate Models in Organ Transplantation
}

\author{
Douglas J. Anderson and Allan D. Kirk \\ Emory Transplant Center, Emory University School of Medicine, Atlanta, Georgia 30322 \\ Correspondence: adkirk@emory.edu
}

\begin{abstract}
Large animal models have long served as the proving grounds for advances in transplantation, bridging the gap between inbred mouse experimentation and human clinical trials. Although a variety of species have been and continue to be used, the emergence of highly targeted biologic- and antibody-based therapies has required models to have a high degree of homology with humans. Thus, the nonhuman primate has become the model of choice in many settings. This article will provide an overview of nonhuman primate models of transplantation. Issues of primate genetics and care will be introduced, and a brief overview of technical aspects for various transplant models will be discussed. Finally, several prominent immunosuppressive and tolerance strategies used in primates will be reviewed.
\end{abstract}

\begin{abstract}
A nimal experimentation has long provided Aa rational basis for the translation of treatments and techniques from the bench to the bedside. In general, all first-in-human trials require preparative animal experimentation to allow patients to make truly informed decisions about their participation. Properly designed animal studies in relevant species provide the necessary background experience with a novel approach to reasonably anticipate the efficacy or, at the very least, safety of a planned intervention. As such, they serve as a foundation on which human trials can be ethically designed, particularly in fields such as immunology, in which the complexity of the interactions involved has prevented the development of any sufficiently predictive in vitro model. Although animal models are far superior to in vitro models in projecting the potential of an approach, it must be recognized that they do not mimic clinical transplantation precisely, and thus cannot be expected to forecast the ultimate experience in humans.
\end{abstract}

The mouse model has formed the backbone of medical research and development for many years owing to the relative ease of breeding and genetic manipulation of the animals at a comparatively low cost. For immunology research, the mouse immune system offers sufficient homology for pathway determination and mechanistic studies, and indeed represents the ideal platform for this type of endeavor. In contrast, the large animal models (dog, pig, and primate) are significantly more expensive and, with the exception of inbred miniature swine (Sachs 1992; Mezrich et al. 2003), exhibit increased genetic diversity, making definitive mechanistic studies much more difficult, if not impossible. However, this complexity makes large animals suited to preclinical studies, in which the addition of often-unanticipated variables allows for the examination of practicality, safety, and generalized efficacy. In general, mice define pathways, and large animal models help establish whether a particular pathway's effect is suffi-

Editors: Laurence A. Turka and Kathryn J. Wood

Additional Perspectives on Transplantation available at www.perspectivesinmedicine.org

Copyright (C) 2013 Cold Spring Harbor Laboratory Press; all rights reserved; doi: 10.1101/cshperspect.a015503

Cite this article as Cold Spring Harb Perspect Med 2013;3:a015503 
ciently robust to emerge as dominant in the midst of the numerous uncontrolled variables typical of heterogeneous human populations.

In specific regard to transplantation immunology, mice have several potential drawbacks. Laboratory mice bred in clean environments and studied between 4 and 8 weeks old have a largely naïve immune system (Blattman et al. 2002), a fact likely responsible for the success of therapies, including methods of tolerance induction, in mice, and their subsequent failure when translated to large animals (Kirk 2003; Sachs 2003), or mice exposed to pathogens (Adams et al. 2003). Additionally, mice do not constitutively express class II antigens on vascular endothelium, unlike other large animal models, which may explain the importance of class II matching in the large animals models (Pescovitz et al. 1984; Choo et al. 1997). Furthermore, the efficacy of any regimen may also be dependent on the strain of mice used (Williams et al. 2000). The relative genetic diversity and immunologic experience of large animals helps to avoid many of these shortcomings, and, indeed, experimentation in a large animal model, most frequently primates (for reasons discussed below), has become a de facto requirement before initiation of human trials in transplantation (Sachs 2003; 't Hart et al. 2004).

The complexities of the immune response often cause therapies to fail in transition to large animals, or to humans. This is most often owing to one or a few critical differences between species rather than a failure of the concept. Interspecies differences in drug pharmacokinetics may lead to apparent failure of a regimen that may have been successful if adjustments for distribution or metabolism had been considered. Furthermore, modern biologic and antibodybased therapies may be profoundly altered by minor differences in molecular structure of the target molecule. The immunologic diversity of large animals can lead to significant differences in outcome via heterologous immune interactions, an experimental parameter that is challenging to quantify and control for. Finally, the practicalities of animal husbandry during treatment can only approximate the care human patients receive. Indwelling catheters and wound care in surgical models are often difficult. Mon- itoring and vascular access is challenging in conscious animal models, often limiting the options for drug delivery and dosing schedules.

Another potential issue with large animal models is that of time, both in terms of the animal's age and survival of grafts. For practical reasons, adolescent animals are often used, and evidence suggests that these young animals, like young humans, have a predominately naïve immune system that will mature toward a memory phenotype as the animal ages (Nan et al. 1998a,b; Rodriquez-Carreno et al. 2002; Saalmüller et al. 2002). With regard to graft survival in animals, convention has established 100 days as indicative of acceptance in mouse models, whereas in larger animals, several years has been the norm. However, although this is practical in terms of the shorter life span and cost of maintaining the animals, no data support that graft survival should be interpreted proportionally to lifespan. Thus, data from these studies should be interpreted for what it is, and not extrapolated to indicate longer survival in longerlived animals (Kirk 2003).

A full review of the ethical principles surrounding animal experimentation is beyond the scope of this article. However, it is worth noting that no animal experiment can be ethical unless it has a reasonable chance of answering a worthwhile question. Specific guidance for ethical treatment of animal subjects can be found in the Guide for the Care and Use of Laboratory Animals (National Research Council 2011) and in the publications of the American Association for Laboratory Animal Care (www.aaalac. org/resources). In general, all animal experiments should embrace the principles of reduction, replacement, and refinement. Animal models should be reserved for when no reasonable alternative exists, and any procedure should be maximally refined for the benefit of the animal's welfare. Any experiment should be designed to minimize the number of animals used without endangering the ability of the experiment to answer the question at hand. An experiment that fails to answer the question posed using fewer animals is less ethical than an experiment that succeeds using more animals, and is virtually useless. 
Primate Models in Organ Transplantation

The choice of large animal model can often be daunting. Dogs, pigs, and nonhuman primates have all been used extensively in transplantation research, and each has sufficient anatomic and physiologic similarity to humans to be useful. In this article we will focus on primates, as that model has become the predominant model used owing to the need for highly conserved targets when testing biologic and antibody-based therapies. However, primates are not a model of convenience, and should be considered only when a therapy is being anticipated for translation to humans, and data are required to facilitate this transition in a safe and ethically viable fashion.

\section{PRIMATE MODELS OF TRANSPLANTATION}

Primate studies in transplantation have used a variety of species, including baboons, macaques, and, rarely, chimpanzees. Chimpanzees offer the highest degree of homology with humans, even serving (historically) as graft donors for humans (Reemtsma 1969); however, their endangered status and evolutionary stature have raised questions regarding the ethics of their use and led to increased restrictions, rendering them a historical model only. Indeed, the National Institutes of Health (NIH) has now eliminated the chimpanzee as a funded model. Baboons have commonly been used in xenotransplantation studies, as their relatively large size better accommodates the porcine organs. Macaques (cynomolgus, rhesus, and pigtail) are the most widely used of the nonhuman primates (NHPs) owing to their small size, defined major histocompatibility complex (MHC), and relative ease of care. Macaques are sufficiently homologous with humans such that most molecular targets will cross-react, with the notable exception of CD3. The remainder of this article will focus predominantly on the rhesus macaque. Numerous applications are described to provide the reader with a general knowledge of the procedures performed using NHPs. For specific methodological detail, the reader is referred to the primary literature (Kirk et al. 1997; Pierson et al. 1999; Hausen et al. 2000a; Elster et al. 2001a; Adams et al. 2002; Cendales et al. 2005).

\section{Genetics in Primate Transplantation}

In human studies of transplantation, the MHC matching of donor-recipient pairs is often known. Although the effect of MHC disparity on outcome varies by organ, generally, bettermatched pairs have better results. The same can be said of primates; however, until recently, MHC typing of primates was difficult, based on incomplete mapping of the region, and frequently omitted. Although NHPs cannot be readily inbred to the same extent as mice, or even dogs or pigs, they are not truly outbred either. Most monkeys used in research are from dedicated colonies with limited interbreeding. The genetic disparity of potential transplant pairs was established using relatively limited techniques, usually mixed lymphocyte reactions and analysis of the DR region. Failure to adequately control for this experimental variable introduces a significant confounding factor in the interpretation of results.

Recent studies of the rhesus macaque paired with technological advances have begun to allow for easier assessment of MHC matching. The rhesus MHC is located on chromosome 4 and, owing to significant duplication of class I A and $\mathrm{B}$ genes (known as mamu-A and mamu-B) and, to a lesser extent, class II duplication, is significantly larger than the human $\mathrm{MHC}$. Owing to the duplication of these genes, individual animals express up to four mamu-A genes and 14 mamu-B genes per chromosome (Kean et al. 2012). Furthermore, these genes are expressed in a hierarchical pattern rather than the codominant expression seen in humans (Otting et al. 2005). The combination of these two facts makes the rhesus MHC extremely complex, particularly for heterozygotes, and renders allele-specific DNA-based typing ineffective at predicting the expression of MHC molecules. Recently, several DNA microsatellite probes were identified that allowed for the determination of autosomal and sex chromosome inheritance between generations of macaques. This allowed for accurate pedigrees to be developed of rhesus breeding groups and determination of inheritance of complete MHC haplotypes (Andrade et al. 2004; Penedo et al. 2005). The de- 
velopment of massively parallel pyrosequencing allowed for comprehensive analysis of $\mathrm{MHC}$ expression (Wiseman et al. 2009) and confirmed the extreme complexity of the rhesus MHC. Pyrosequencing can be used to determine the complete MHC type for any individual animal. By combining these two technologies, investigators can design experiments with knowledge of the MHC disparity between potential transplant pairs, greatly increasing the validity of the results. To do so, however, requires substantial coordination with the primate breeding facility, and advanced planning to achieve the desired degree of match or mismatch while still minimizing the number of animals used.

\section{Perioperative Care}

The perioperative and follow-up care of NHPs can only approximate what is available for humans. Routine care and treatment of any complications should be performed in consultation with veterinary staff and be anticipated within the animal use protocols approved by the Institutional Animal Care and Use Committee (IACUC). The animal's clinical status should be monitored frequently, as changes in activity or appetite are often early signs of rejection, infection, or technical complications. Animals receiving nephrotoxic immunosuppression or those that receive renal grafts should be monitored for urine output. Laboratory values should be checked routinely postoperatively and with any clinical changes. Medications can be delivered by a number of routes; however, care should be taken when planning experiments to avoid overly frequent sedation for intravenous infusions. Medications requiring daily dosing should be given by mouth or by subcutaneous or intramuscular injection, if possible, unless specialized cages allowing for indwelling catheters in conscious animals are available. Anorexic or malnourished animals can receive supplemental nutrition via orogastric tube while sedated, and should be referred to veterinary staff for dietary modifications. Clinical medications analogous to the standard medications used for human transplantation, such as antibiotics or analgesics, are generally available through veter- inary protocols, and although many require dose adjustments, most human agents work well in rhesus macaques. Finally, animals receiving immunosuppression should be monitored for the development of infections, and prophylaxis can be considered. Polymerase chain reaction (PCR)-based assays for rhesus macaque homologs of CMV and EBV, rhCMV (Yue and Barry 2008) and LCV (Rao et al. 2000; Rivailler et al. 2004), respectively, are available for monitoring. Regular monitoring of transplanted animals can provide insight into the extent of immunosuppression, and perhaps, indicate when a regimen may excessively compromise protective immunity (Lo et al. 2013; Lowe et al. 2013).

\section{Renal Transplantation}

Renal transplantation in primates mimics the intra-abdominal procedure used in small children. Following systemic heparinization of both the donor and recipient, the donor organ is excised and the vessels are anastamosed to the recipient's infrarenal aorta and vena cava (Fig. 1). Typically this is performed in a left-to-right fashion owing to the longer length of the left renal vessels. The donor ureter is tunneled through the retroperitoneum and a primary ureteroneocystostomy is formed, typically on the posterior wall of the bladder using a modified Leadbetter-Politano approach (Politano and Leadbetter 1958; Kayler et al. 2010). The recipient's native kidney(s) are removed following implantation (Kirk et al. 1997; Knechtle et al. 1997). When possible, the animals may be paired in a domino fashion, allowing each individual to act as a donor and recipient, reducing the number of animals needed and preventing the need for a simultaneous bilateral retroperitoneal dissection and native nephrectomy, which is particularly stressful for the animals. In general, renal transplantation is well tolerated by the animals and complications are limited, with most issues related to the ureter (Song et al. 2010).

\section{Skin Transplantation}

Like renal transplantation, skin transplantation in primates is relatively straightforward, and 

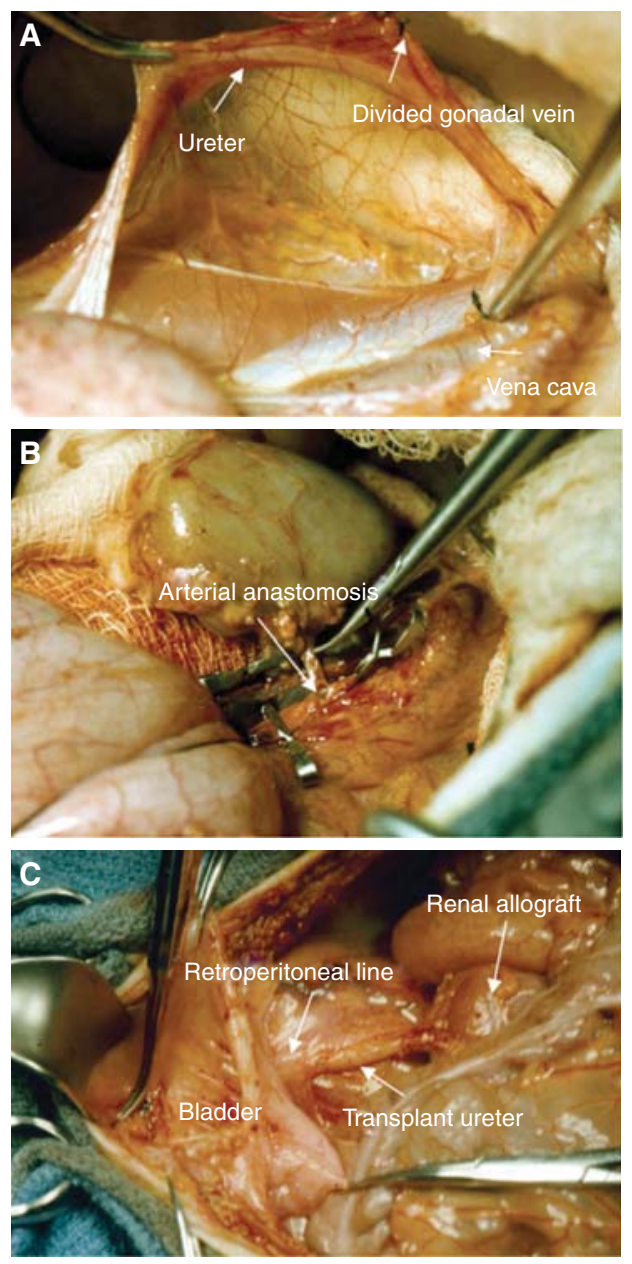

Figure 1. Primate renal transplantation. (A) A retroperitoneal pocket is created starting medial to the native ureter and moving laterally. $(B)$ The donor vessels are anastomosed to the recipient vena cava and aorta. $(C)$ Following reperfusion, the donor ureter is tunneled through the retroperitoneum to a posterior cystotomy and anchored within the bladder.

offers a rigorous model in which to test immunosuppressive or tolerance strategies (Elster et al. 2001b). Donor grafts are typically taken from the abdominal wall and implanted on the back of the recipient to reduce the likelihood of the animal picking at the graft. It is important to remove cutaneous fat from the skin graft before transplantation, and similarly important not to remove subcutaneous tissue and microvasculature from the recipient site. To further protect
Primate Models in Organ Transplantation

the grafts during healing, soft bolsters should be used to hold the graft against the underlying tissue (Fig. 2). These can be removed after approximately 1 week. The animals also need to wear protective jackets to protect the grafts and bandages from damage during grooming. The animals generally need to acclimatize to wearing the jacket for a period of time preoperatively, and this may take several weeks before the primate is comfortable with the jacket.

\section{Islet Transplantation}

Nonhuman primates have been used extensively in the study of pancreatic islet transplantation. Following a period of training the animals for frequent glucose monitoring, the animals can be rendered diabetic by pancreatectomy or injection of streptozotocin, and diabetes is confirmed by the absence of native c-peptide pro-
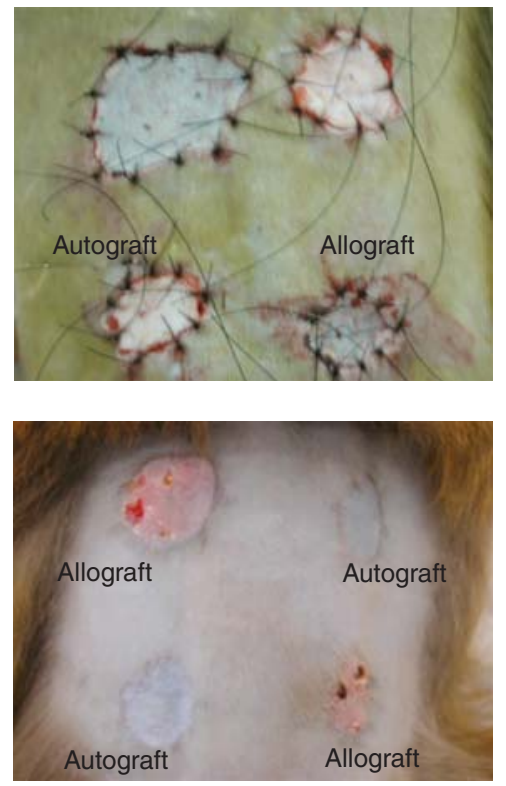

Figure 2. NHP skin grafts. In the upper panel, grafts have been sewn in place and anchor sutures placed. The sutures are left long so that they can be used to affix cotton bolsters over the grafts to stabilize the grafts for approximately 1 week. In the lower panel, the grafts are shown after having healed to the underlying tissue. Note that the allografts are undergoing early rejection and appear erythematous when compared with the autografts. 
duction. Islet cells from the donor pancreas are isolated in the same manner in which human islets are isolated and then infused into the portal circulation by gravity (Adams et al. 2002; Badell et al. 2012a), although other sites for islet implantation are being investigated (Cantarelli and Piemonti 2011). Daily fasting and postprandial blood sugars can be easily monitored postoperatively to assess engraftment and survival of the islet cells. Histological implantation, rejection, and function all closely approximate human islet transplantation.

\section{Heart and Lung Transplantation}

The use of NHPs in studies of allogenic heart and lung transplantation is less common; however, examples do exist of their use (Hausen et al. 2000a,b; Azimzadeh et al. 2006). More frequently, primates are used as recipients of heart or lung grafts in studies of xenotransplantation, which will be discussed briefly below and more extensively in other portions of this text. Heart transplantation in primates is typically performed in a heterotopic fashion with the graft placed in the abdominal cavity (Pierson et al. 1999). The graft can then be followed by palpation, ultrasound, or even implanted EKG electrodes ( $\mathrm{Li}$ et al. 2011). Larger NHPs, such as the baboon, or the cynomolgus macaque are often used in these procedures for technical reasons.

\section{Vascularized Composite Allografts}

Advances in immunosuppression and microsurgical technique has allowed for the transplantation of multiple tissues as a functional unit, such as hand and face transplantation. Multiple primate models of these vascularized composite allografts have been developed. Models involving either a portion of or whole hand transplantation in primates (Stark et al. 1987; Hovius et al. 1992) potentially negatively affect the function of the surviving recipient. Cendales et al. (2005) developed a model in which only a small portion of the radial forearm is transplanted, allowing for preserved function in both the donor and recipient (Fig. 3). A heterotopic model of facial transplantation has also been developed by a group at the University of Maryland involving part of the mandible, overlying soft tissue, skin, and vasculature (Silverman et al. 2008; Barth et al. 2009).

\section{Xenotransplantation}

Xenotransplantation is covered more extensively in another article in this collection, so we will mention it here only briefly. Studies of xenotransplantation in primates frequently use swine as the organ donor, owing to the ease of breeding and genetic manipulation, such as knockouts of the Gal antigen (Lai et al. 2002; Phelps et al. 2003; Kolber-Simonds et al. 2004; Nottle et al. 2007). Baboons are typically used for solid organ xenotransplant experiments, as their larger size better accommodates the porcine organs. Macaques are often used as recipients of xenoislet transplants. When planning these experiments, it is worth noting that cynomolgus macaques have lower resting blood glucose levels than humans (Casu et al. 2008). Although choosing an ideal donor age has provided some controversy in these experiments, both adult and neonatal islets have been successfully transplanted (Cardona et al. 2006, 2007; Hering and Walawalkar 2009; Thompson et al. 2011).

\section{STANDARD IMMUNOSUPPRESSION}

Virtually all clinically used standard immunosuppressants have been found to be successful in prolonging graft survival in primate models, particularly when adjustments for distribution and metabolism have been considered. To focus on the relatively newer immunosuppressants and biologic therapies, we will mention the conventional immunosuppressants, which have been reviewed extensively elsewhere (Kirk 2003), only briefly.

Both azathioprine and mycophenolate have been successfully used in primate models of transplantation, as have calcineurin inhibitors. The development of tacrolimus is worth particular mention, as it was tested in a canine model first with promising results but significant toxicity. Only after follow-up studies in primates that showed its safety was the drug translated 

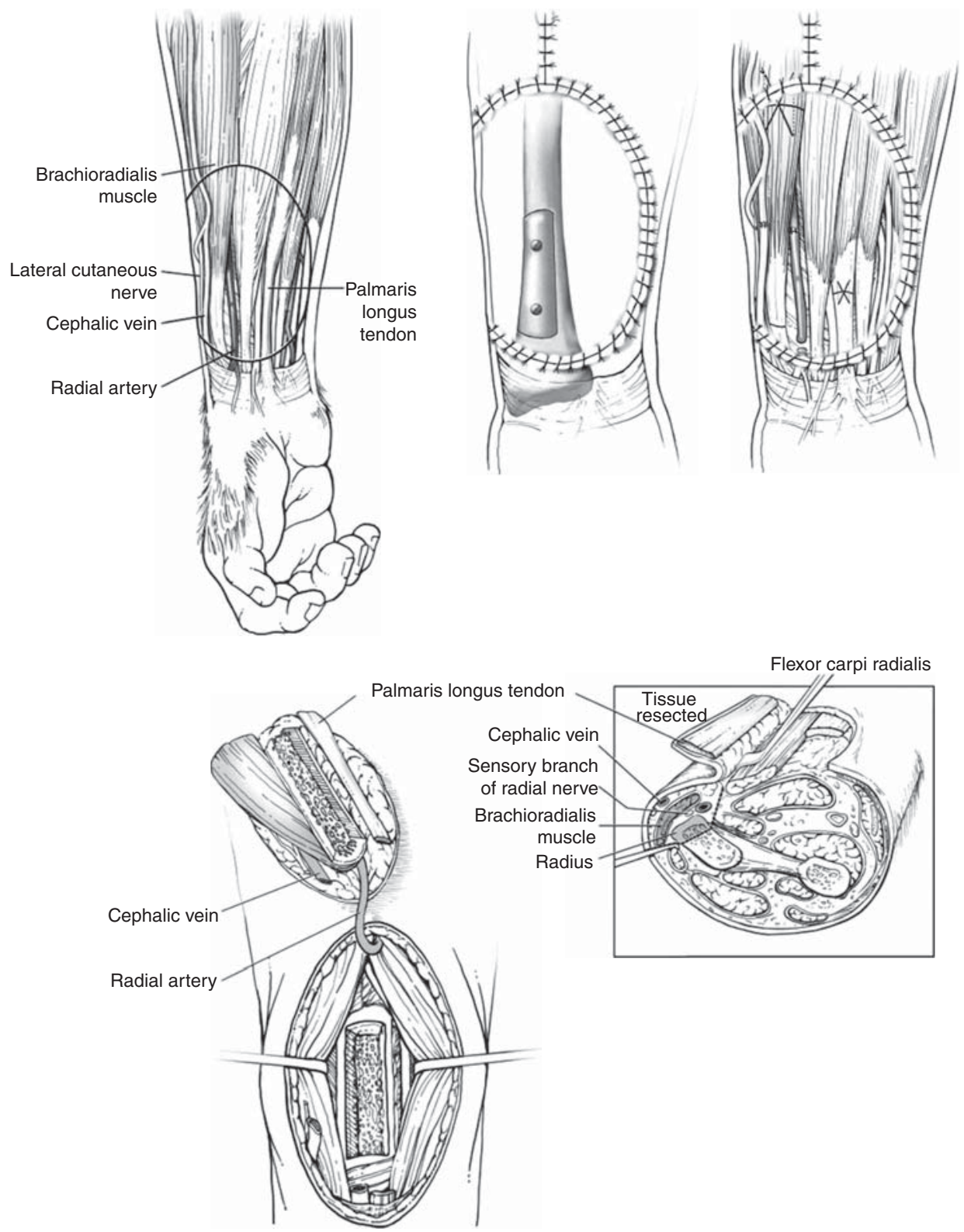

Figure 3. Radial forearm vascularized composite allotransplantation (VCA) containing bone, muscle, tendon, nerve, vasculature, subcutaneous fat, and skin. (From Cendales et al. 2005; reprinted, with express permission, from the author.)

to human use (Todo et al. 1988). A cyclosporinebased regimen has even been shown to induce tolerance in a partially MHC-matched rhesus model (Jonker et al. 1998). Given their success and almost universal use in human transplantation, the calcineurin inhibitors remain a fre- quently studied class of immunosuppressants, either in combination with new agents or as a control against which the new agent is tested. They are dosed at somewhat higher levels compared with humans dosing to achieve therapeutic targets. The mTOR inhibitor sirolimus has 
been frequently studied in primate models and been found to prolong graft survival alone (Weaver et al. 2009; Lo et al. 2013) or in combination with tacrolimus (Chen et al. 2000). However, it has been shown to have significant gastrointestinal toxicity in rhesus macaques (Montgomery et al. 2002a). Sirolimus has also been used in combination with Tregulatory cell therapy to prolong renal graft survival in the rhesus model (Ma et al. 2011). Everolimus, another mTOR inhibitor, has also been successfully used in primate models of lung (Hausen et al. 2000b) and islet transplantation (Wijkstrom et al. 2004).

A bevy of newer immunosuppressants have also been tested in primate models. FTY720, which prevents the egress of lymphocytes out of lymph nodes, prolongs renal graft survival in macaques, either alone or in combination with other agents (Schuurman et al. 2002). Sotrastaurin, a selective protein kinase $\mathrm{C}$ inhibitor, also prolongs primate renal graft survival (Bigaud et al. 2012). It too was found to synergize with other agents, including the aforementioned FTY720 (Bigaud et al. 2006, 2012). The Janus kinase 3 inhibitor, tofacitinib (CP$690,550)$, was used in a cynomolgus renal transplant model and was shown to prolong graft survival and decrease circulating natural killer (NK) and T-cell populations, a result interpreted to be consistent with multiple cytokine blockade (Borie et al. 2005). Finally, a study of PG490-88, a prodrug form of triptolide, showed prolonged renal allograft survival in cynomolgus monkeys (Chen et al. 2006).

\section{COSTIMULATION BLOCKADE}

The blockade of costimulatory signals has repeatedly been used to induce tolerance in rodent models (Turka et al. 1992; Pearson et al. 1994; Larsen et al. 1996). However, the translation of these strategies to large animal models has been less successful. Two phenomena are believed to be primarily responsible for this discrepancy. First, more outbred animals will have a higher precursor frequency, and the alloreactive immune cells are capable of overcoming costimulation blockade by sheer numbers (Ford et al.
2007). Antigen recognition inefficiently generates some response in the absence of costimulation, and the high precursor frequency makes up for this inefficiency, allowing for an immunologically meaningful response (Viola and Lanzavecchia 1996; Germain 2001). Second, there are some cell populations, such as memory $\mathrm{T}$ cells, that appear to be less dependent on costimulation (London et al. 2000); thus, more experienced immune systems will be more apt to respond to antigen even during costimulatory blockade. In this review, we will focus on the CD28-B7 and CD40-CD154 pathways, which are the most extensively studied of the costimulatory pathways. However, as the role of costimulation has been increasingly studied, multiple receptor-ligand pairs have been discovered, and it is now generally accepted that multiple ancillary pathways exist to modulate the immune response (Ford and Larsen 2009; Pilat et al. 2011). Owing to the highly specific nature of the biologic agents used to block these signals, primate models have become the large animal model of choice for these studies (Kirk 1999).

Of existing costimulation blockade strategies, blockade of the CD28-B7 pathway has reached the furthest clinical development, with the FDA approval of belatacept for use in human kidney transplantation in July of 2011. Early work to study blockade of the CD28 pathway involved monoclonal antibodies against the B7 ligands CD80 and CD86. Three groups showed prolongation of renal allograft survival using the antibodies 1F1 and 3D1 either alone or in combination with other immunosuppressants (Hausen et al. 2001; Kirk et al. 2001; Montgomery et al. 2002b; Birsan et al. 2003). Another group used different clones, B7-24 and 1G10, in rhesus skin and renal transplant models with modest success (Ossevoort et al. 1998a,b). Despite these successes, further development of these antibodies was abandoned, as it was shown that both B7 molecules needed to be blocked to have efficacy (Kirk et al. 2001), and the B7-specific fusion protein approach accomplished this with a single agent, thus simplifying development plans.

A second strategy to block the CD28 pathway is via the soluble form of the CTLA4 recep- 
tor, the fusion protein CTLA4-Ig, which binds both B7 ligands. Following success in several rodent models (Pearson et al. 1994; Akalin et al. 1996; Bolling et al. 1996), early studies in multiple primate models showed only modest prolongation of graft survival (Kirk et al. 1997; Levisetti et al. 1997; Krieger et al. 1998). Persistent interest in this pathway led to the development of belatacept, which differs from the base CTLA4-Ig protein by only two amino acids, but shows significantly higher inhibition of CD28 signaling (Larsen et al. 2005). Belatacept was shown to be effective as maintenance therapy in primate models of islet and renal transplantation (Cardona et al. 2006; Lo et al. 2013; Lowe et al. 2013), and subsequent clinical trials led to its successful translation to human use.

Blockade of the CD28 pathway via targeting of the B7 ligands has the potential drawback of blockade of inhibitory signals through CTLA4, and significant interest exists in developing therapeutics that will simultaneously block CD28 signaling while leaving CTLA4 signaling intact. The use of full monoclonal antibodies directed against CD28 was set back by the disastrous results of the TGN1412 trial, in which an antiCD28 antibody with superagonistic qualities caused life-threatening inflammatory responses in all six human volunteers who received the drug (Suntharalingam et al. 2006). Although several recommendations have been made for the design of future trials to avoid a repeat of the TGN141 trial (Stebbings et al. 2007; Findlay et al. 2010), there has been, understandably, extreme caution in developing antibodies against CD28. Since TGN1412, two trials using modified CD28 antibodies have been reported: the monovalent fusion antibody sc28AT has been shown to prolong primate graft survival (Poirier et al. 2010), and a pegylated monovalent Fab' antibody, FR104, has been promising in rodent models, but thus far only pharmacokinetic studies have been reported in primates (Poirier et al. 2012).

The CD40-CD154 pathway has also been extensively studied in primate models. The monoclonal antibody hu5C8, directed against CD154, has been shown to be efficacious in multiple primate transplant models involving several or- gans (Kenyon et al. 1999a,b; Kirk et al. 1999; Pierson et al. 1999; Elster et al. 2001b; Xu et al. 2001). Similarly, two other antibodies against CD154, IDEC-131 and ABI793, have been shown to prolong graft survival in primate models (Pfeiffer et al. 2001; Pierson et al. 2001; Xu et al. 2001, 2003; Kanmaz et al. 2004; Schuler et al. 2004; Preston et al. 2005; Azimzadeh et al. 2006; Pearl et al. 2007). Somewhat fortuitously, hu5C8 was one of the first antibodies to be tested at the relatively high dose of $20 \mathrm{mg} / \mathrm{kg}$. This was important, as it was later discovered that CD154 was present on multiple cell types throughout the body, offering large quantities of the ligand to compete for binding, and, in some cases, initiate rejection (Xu et al. 2006). It is possible that the efficacy of CD154 blockade would not have been appreciated had a lower dose been used. Unfortunately, however, the widespread distribution of CD154, particularly on platelets, has led to concerns regarding the thromboembolic potential of CD154-directed therapies, and this has limited the clinical development of these therapies (Kawai et al. 2000).

The success of the CD154 antibodies prompted continued investigation of the pathway, focusing on CD40. Multiple antibodies against CD40 have been tested, with efficacy on graft survival and effect on B-cell populations depending on the clone used: Chi220 (Pearson et al. 2002; Adams et al. 2005), 3A8 (Badell et al. 2012a,b; Page et al. 2012a), 4D11 (Imai et al. 2007; Aoyagi et al. 2009), ch5D12 (de Vos et al. 2004), or 2C10 (Lowe et al. 2012).

The combination of CD28-B7 and CD40CD154 pathway blockade has been studied on multiple occasions. Depending on the agents used, the combination has only sometimes provided a graft survival advantage over either agent alone. However, even in cases in which no synergy was seen in terms of graft survival, there does appear to be an advantage of combination therapy in abating the humoral response (Ossevoort et al. 1998b; Montgomery et al. 2002b). Clearly, as our understanding of these and other costimulatory pathways improves, there will be plenty of opportunity to further develop strategies to take advantage of these molecules for immune modulation. 
D.J. Anderson and A.D. Kirk

\section{ADHESION BLOCKADE}

A number of surface molecules on immune cells mediate the interaction between these cells, their environment, and each other. Many of these adhesion molecules are important for cell trafficking and homing, whereas some have been found to stabilize the immune synapse, and even provide costimulatory signals. This section will focus on two prominent adhesion molecules in transplantation experiments.

The integrin LFA-1 is the most extensively studied of the adhesion molecules. It has been shown to be important in cell trafficking and homing (Hamann et al. 1988; Kavanaugh et al. 1991; Warnock et al. 1998), antigen presentation (Moy and Brian 1992; Pribila et al. 2004), and costimulation (Van Seventer et al. 1990; Nicolls and Gill 2006). The apparent importance of LFA-1 in multiple areas of the immune response prompted significant interest as a strategy for immunosuppression. Anti-LFA-1-based regimens have been successful in prolonging graft survival in primate models of skin (Berlin et al. 1992), cardiac (Poston et al. 2000), and islet transplantation (Badell et al. 2010). Translation of these strategies to human use has been challenging. Studies of the humanized antiLFA-1 agent, efalizumab, in kidney (Vincenti et al. 2007) and islet (Turgeon et al. 2010) transplantation were promising. However, the drug, which was widely used for psoriasis, was found to be the cause of four cases of progressive multifocal leukoencephalopathy in that population, and was removed from the market. Any future anti-LFA-1-based regimens will likely need to be more selective in their blockade to avoid deleterious effects on protective immunity.

The interaction of CD2 and LFA-3 primarily strengthens the interaction of T cells and antigen-presenting cells (APCs), but also, like LFA1 , is capable of transducing costimulatory signals directly (Bromgerg 1993). Multiple agents to block this interaction have been developed with modest results in primate models (Kaplon et al. 1996; Dehoux et al. 2000). Weaver et al. (2009) used the fusion protein alefacept (LFA3Ig) in addition to CTLA4-Ig in a rhesus renal transplant model with significant prolongation of graft survival. However, a subsequent study by the same group, which replaced CTLA4-Ig with belatacept, showed no benefit with the addition of alefacept and an increase in viral infections in both renal and islet models (Lo et al. 2013; Lowe et al. 2013). Clearly, further experiments will be needed to clarify the role of CD2 blockade in the future.

Much like the exploding number of costimulatory receptor-ligand pairs that have been discovered over recent years, increasing numbers of adhesion molecules are being discovered and studied. As our understanding of these molecules improves, it is likely we may be able to exploit these pathways to modulate the alloimmune response. One such candidate is the integrin VLA-4, for which an agent, natalizumab, is already approved for use in multiple sclerosis, making it an ideal candidate for translation for use in transplantation.

\section{DEPLETION}

One strategy to deal with the aforementioned issue of relatively high precursor frequency and sensitization is to remove those cells from the body before transplantation. Thus, lymphocyte depletion is seen as an adjuvant to other therapies in the development of tolerance regimens. However, at present there are no readily available NHP-specific depletional agents; thus, human specific preparations are used. These have efficacy in NHPs, but they do not mimic the effects seen in humans. Thus, NHP models are not as satisfactory for studying depletion as they are for the more specific pathway blockade described above.

Lymphocyte depletion with polyclonal preparations was one of the first strategies developed. These preparations include both antilymphocytic antibodies as well as antibodies against a variety of other cell-surface molecules, particularly adhesion molecules, which may be of use in cases in which ischemic injury leads to activated endothelium providing an interface for leukocyte adhesion and migration (Hammer and Thein 2002). Rabbit antithymocyte globulin (ATG) must be given in much higher doses in primates than humans, likely owing to 
decreased specificity for NHP epitopes, notably CD3 (Preville et al. 2001). ATG has been shown to prolong primate graft survival (Thomas et al. 1978); however, its dosing requirements, halflife, and specificity differ so significantly from that seen in humans (the species to which ATG is raised) that it is unlikely that ATG's behavior in NHPs is a satisfactory surrogate for its use in the clinic. ATG fails to induce tolerance in most models, and is thus used primarily as induction therapy followed by some form of maintenance therapy, a variety of which have been successful (Hirshberg et al. 2003; Liu et al. 2007). However, a study by Haanstra et al. (2006) found that ATG combined with costimulation blockade shortened the time to rejection, possibly owing to decreased intragraft inhibitory molecules. The lymphocyte repopulation following depletion with ATG relatives enriches memory populations (Pearl et al. 2007), potentially with lower costimulation requirements.

A variety of monoclonal antibodies have been developed to eliminate or incapacitate reactive effector T cells. Depletion with CD3 and CD4 antibodies conjugated to idarubicin allowed for operational tolerance in half of baboon kidney grafts when paired with TLI, but only when given preoperatively (Myburgh et al. 2001). However, use of a nondepleting antibody, OKT4A, only modestly prolonged graft survival (Cosimi et al. 1990; Wee et al. 1992; Mourad et al. 1998). Depletion based on another potential target, CD45RB, has been shown to prolong graft survival in cynomolgus macaques (Chen et al. 2007). B cells have also been targeted in depletional studies, with the agent rituximab showing prolongation of graft survival in primate islet (Liu et al. 2007) and cardiac models (Kelishadi et al. 2010).

The most promising results in NHP lymphocyte depletion have been achieved using immunotoxin (IT), a fusion of a modified diptheria toxin with a monoclonal antibody against CD3 (Neville et al. 1996; Ma et al. 1997). Knechtle has been able to show pretransplant depletion with IT promotes tolerance in renal transplant models (Knechtle et al. 1997, 1998a). Despite the ability of IT to reverse rejection in a rhesus renal transplant model (Knechtle et al. 1998b), it has been somewhat less effective at prolonging graft survival when given at the time of transplant rather than beforehand (Armstrong et al. 1998; Jonker et al. 2002). The development of a humoral response leading to graft loss in these models using chemically linked IT, or the somewhat less effective recombinant IT (Ma et al. 1997; Kim et al. 2007), has been proposed as a useful model of chronic allograft rejection (Torrealba et al. 2003; Page et al. 2012b).

\section{CHIMERISM}

Chimerism has long been studied as a method of inducing allograft tolerance, dating to the studies of Owen (1945) in freemartin cattle, and later Medawar and colleagues (Billingham et al. 1956). Hematopoietic chimerism can be classified based on the relative number of donor cells in the general cell population. Infusion of hematopoietic stem cells into an unconditioned recipient leads to rapid rejection of the cells and failure to engraft. Microchimerism, in which $<1 \%$ of circulating cells are of donor origin, and these are only detectable by very sensitive techniques such as PCR, is the most this model can produce. Establishment of mixed chimerism ( $>1 \%$ but $<100 \%$ ) or especially full chimerism $(\sim 100 \%)$, requires more intensely ablative conditioning of the recipient. The potential toxicity of these conditioning regimens has been a major barrier to clinical translation of chimerism-based approaches, given the relative safety of modern immunosuppression.

Donor-specific marrow infusions without ablative preconditioning have been studied in attempts to prolong primate allograft survival. However, it is worth noting that all transplant recipients are likely microchimeric to some degree (Starzl et al. 1992), and this does not lead to widespread tolerance. It is possible the establishment of microchimerism is thus simply a marker for sufficient immunosuppression (Wood and Sachs 1996).

Full chimerism, in which virtually all of the hematopoietic cells are of donor origin, is generally only achievable following intense conditioning in HLA identical siblings, if graftversus-host-disease (GvHD) is to be avoided. 
However, there are multiple reports of full chimerism inducing donor-specific tolerance of subsequent renal grafts (Sayegh et al. 1991; Helg et al. 1994; Jacobsen et al. 1994) in humans. Full chimerism does have some drawbacks, however, both in the risk of GvHD and an apparent immune incompetence likely owing to MHC disparity between donor-derived immune cells and recipient-derived APCs (Sykes 2001).

Based on the studies of microchimerism, it is generally accepted that macrochimerism is necessary for durable tolerance to develop, and the drawbacks and impracticalities of full chimerism approaches have made mixed chimerism an area of intense study. A group in Boston has induced mixed chimerism in cynomolgus macaques using irradiation, bone marrow infusion, T-cell depletion, and splenectomy across MHC barriers without GvHD (Kawai et al. 1995; Kimikawa et al. 1997). These animals accepted renal allografts from their marrow donors and, in most cases, also did not produce donor-specific antibodies (Kawai et al. 1999). However, results in cardiac transplantation were somewhat less promising (Kawai et al. 2002), and this regimen also induced increased rates of posttransplant lymphoproliferative disorder (PTLD), likely related to lymphocryptovirus (LCV) in monkeys (Schmidtko et al. 2002). Further refinement of the regimen replaced splenectomy with CD154 blockade (Kawai et al. 2004), and these regimens formed the basis for the first human trial of mixed chimerism (Kawai et al. 2008).

Another group has attempted to induce mixed chimerism in rhesus macaques. In this model, busulfan is the primary conditioning agent, followed by basiliximab, combined costimulation blockade, and sirolimus (Kean et al. 2007). Although the regimen was successful in inducing long-lasting mixed chimerism, the marrow was found to be rapidly rejected once the maintenance immunosuppression was stopped (Larsen et al. 2010), and viral infections continued to be an issue (Kean et al. 2007). Replacing CD154 blockade with CD40 blockade did not prolong marrow graft acceptance beyond the cessation of immunosuppression (Page et al. 2012a). To date, the effect of these mixed chimerism regimens on solid organ transplantation has not been reported. Despite the challenges of chimerism-based approaches to tolerance, they represent one of the few strategies that have been successfully translated to humans, and the promising results of preclinical studies warrant further research into the field.

\section{SUMMARY}

In this article, we have reviewed the use of primates in preclinical studies of transplantation, both in the technical aspects of working with primates, and also a number of strategies to prolong graft survival currently being studied. Some of these approaches have already found their way into the clinic, whereas others are still a far way off, in need of significant refinement before they can become a clinical reality. Primate models of transplantation offer an ideal arena in which to study these therapies and hone their application so they may be of the greatest benefit for our patients.

\section{REFERENCES}

Adams AB, Shirasugi N, Durham MM, Strobert E, Anderson D, Rees P, Cowan S, Xu H, Blinder Y, Cheung M, et al. 2002. Calcineurin inhibitor-free CD28 blockade-based protocol protects allogeneic islets in nonhuman primates. Diabetes 51: 265-270.

Adams AB, Pearson TC, Larsen CP. 2003. Heterologous immunity: An overlooked barrier to tolerance. Immunol Rev 196: 147-160.

Adams AB, Shirasugi N, Jones TR, Durham MM, Strobert EA, Cowan S, Rees P, Hendrix R, Price K, Kenyon NS, et al. 2005. Development of a chimeric anti-CD40 monoclonal antibody that synergizes with LEA29Y to prolong iset allograft survival. J Immunol 174: 542-550.

Akalin E, Chandraker A, Russell ME, Turka LA, Hancock WW, Sayegh MH. 1996. CD28-B7 T cell costimulatory blockade by CTLA4Ig in the rat renal allograft model: Inhibition of cell-mediated and humoral immune responses in vivo. Transplantation 62: 1942-1945.

Andrade MCR, Penedo MCT, Ward T, Silva VF, Bertolini LR, Roberts JA, Leite JP, Cabello PH. 2004. Determination of genetic status in a closed colony of rhesus monkeys (Macaca mulatta). Primates 45: 183-186.

Aoyagi T, Yamashita K, Suzuki T, Uno M, Goto R, Taniguchi M, Shimamura T, Takahashi N, Miura T, Okimura K, et al. 2009. A human anti-CD40 monoclonal antibody, 4D11, for kidney transplantation in cynomolgus monkeys: Induction and maintenance therapy. Am J Transplant 9: 1732-1741.

Armstrong N, Buckley P, Oberley T, Fechner J, Dong YC, Hong XN, Kirk A, Neville D Jr, Knechtle S. 1998. Analysis 
of primate renal allografts after T-cell depletion with antiCD3-CRM9. Transplantation 66: 5-13.

Azimzadeh AM, Pfeiffer S, Wu G, Schroder C, Zorn GL III, Kelishadi SS, Ozkaynak E, Kehry M, Atkinson JB, Miller GG, et al. 2006. Alloimmunity in primate heart recipients with CD154 blockade: Evidence for alternative costimulation mechanisms. Transplantation 81: 255-264.

Badell IR, Russell MC, Thompson PW, Turner AP, Weaver TA, Robertson JM, Avila JG, Cano JA, Johnson BE, Song M, et al. 2010. LFA-1-specific therapy prolongs allograft survival in rhesus macaques. J Clin Invest 120: 4520 4531.

Badell IR, Russell MC, Cardona K, Shaffer VO, Turner AP, Avila JG, Cano JA, Leopardi FV, Song M, Strobert EA, et al. 2012a. CTLA4Ig prevents alloantibody formation following nonhuman primate islet transplantation using the CD40-specific antibody 3A8. Am J Transplant 12: $1918-1923$.

Badell IR, Thompson PW, Turner AP, Russell MC, Avila JG, Cano JA, Robertson JM, Leopardi FV, Strobert EA, Iwakoshi NN, et al. 2012b. Nondepleting anti-CD40-based therapy prolongs allograft survival in nonhuman primates. Am J Transplant 12: 126-135.

Barth RN, Bluebond-Langner R, Nam A, Stanwix M, Shipley S, Bartlett ST. 2009. Facial subunit composite tissue allografts in nonhuman primates: I. Technical and immunosuppressive requirements for prolonged graft survival. Plast Reconstr Surg 123: 493-501.

Berlin PJ, Bacher JD, Sharrow SO, Gonzalez C, Gress RE 1992. Monoclonal antibodies against human $\mathrm{T}$ cell adhesion molecules-Modulation of immune function in nonhuman primates. Transplantation 53: 840-849.

Bigaud M, Wieczorek G, Preussing E, Riesen S, Cordoba F, Audet M, Blancher A, Heusser C, Bruns C, Wagner J, et al. 2006. NVP-AEB071 (AEB), the novel oral inhibitor of protein kinase $\mathrm{C}$ (PKC) and early T-cell activation, prolongs non-human primates (NHP) kidney allograft survival when combined with everolimus (RAD), ERL080 (ERL) or FTY720 (FTY) without calcineurin inhibitor (CNI). Am J Transplant 6: 251-252.

Bigaud M, Wieczorek G, Beerli C, Audet M, Blancher A, Heusser C, Morris RE, Wagner J. 2012. Sotrastaurin (AEB071) alone and in combination with cyclosporine A prolongs survival times of non-human primate recipients of life-supporting kidney allografts. Transplantation 93: $156-164$.

Billingham RE, Brent L, Medawar PB. 1956. Quantitative studies on tissue transplantation immunity. III: Actively acquired tolerance. Philos Trans R Soc Lond B Biol Sci 239: 357-412.

Birsan T, Hausen B, Higgins JP, Hubble RW, Klupp J, Stalder M, Celniker A, Friedrich S, O'Hara RM, Morris RE. 2003. Treatment with humanized monoclonal antibodies against CD80 and CD86 combined with sirolimus prolongs renal allograft survival in cynomolgus monkeys. Transplantation 75: 2106-2113.

Blattman JN, Antia R, Sourdive DJD, Wang X, Kaech SM, Murali-Krishna K, Altman JD, Ahmed R. 2002. Estimating the precursor frequency of naive antigen-specific CD8 T cells. J Exp Med 195: 657-664.

Bolling SF, Lin H, Wei RQ, Turka LA. 1996. Preventing allograft rejection with CTLA4IG: effect of donor-specific transfusion route or timing. J Heart Lung Transplant 15: 928-935.

Borie DC, Changelian PS, Larson MJ, Si MS, Paniagua R, Higgins JP, Holm B, Campbell A, Lau M, Zhang S, et al. 2005. Immunosuppression by the JAK3 inhibitor CP690,550 delays rejection and significantly prolongs kidney allograft survival in nonhuman primates. Transplantation 79: 791-801.

Bromberg JS. 1993. The biology of CD2: Adhesion, transmembrane signal, and regulatory receptor of immunity. J Surg Res 54: 258-267.

Cantarelli E, Piemonti L. 2011. Alternative transplantation sites for pancreatic islet grafts. Curr Diab Rep 11: $364-$ 374.

Cardona K, Korbutt GS, Milas Z, Lyon J, Cano J, Jiang W, Bello-Laborn H, Hacquoll B, Strobert E, Gangappa S, et al. 2006. Long-term survival of neonatal porcine islets in nonhuman primates by targeting costimulation pathways. Nat Med 12: 304-306.

Cardona K, Milas Z, Strobert E, Cano J, Jiang W, Safley SA, Gangappa S, Hering BJ, Weber CJ, Pearson TC, et al. 2007. Engraftment of adult porcine islet xenografts in diabetic nonhuman primates through targeting of costimulation pathways. Am J Transplant 7: 2260-2268.

Casu A, Bottino R, Balamurugan AN, Hara H, van der Windt DJ, Campanile N, Smetanka C, Cooper DK, Trucco M. 2008. Metabolic aspects of pig-to-monkey (Macaca fascicularis) islet transplantation: Implications for translation into clinical practice. Diabetologia 51: $120-129$.

Cendales LC, Xu H, Bacher J, Eckhaus MA, Kleiner DE, Kirk AD. 2005. Composite tissue allotransplantation: Development of a preclinical model in nonhuman primates. Transplantation 80: 1447-1454.

Chen H, Peng J, Luo H, Loubeau M, Wan X, Xu D, Daloze P, Fitzsimmons WE, Bekersky I, Peets J, et al. 2000. Compromised kidney graft rejection response in Vervet monkeys after withdrawal of immunosuppressants tacrolimus and sirolimus. Transplantation 69: 1555-1561.

Chen G, Sun H, Arp J, Garcia B, Wang X, Wise Y, Liu W, Ramcharran S, Huang X, Xiang Y, et al. 2006. A synergistic effect between PG490-88 and tacrolimus prolongs renal allograft survival in monkeys. Am J Transplant 6: 714-723.

Chen G, Luke PPW, Yang H, Visser L, Sun H, Garcia B, Qian H, Xiang Y, Huang X, Liu W, et al. 2007. Anti-CD45RB monoclonal antibody prolongs renal allograft survival in cynomolgus monkeys. Am J Transplant 7: 27-37.

Choo JK, Seebach JD, Nickeleit V, Shimizu A, Lei H, Sachs DH, Madsen JC. 1997. Species differences in the expression of major histocompatibility complex class II antigens on coronary artery endothelium: Implications for cell-mediated xenoreactivity. Transplantation 64: 13151322.

Cosimi AB, Delmonico FL, Wright JK, Wee SL, Preffer FI, Jolliffe LK, Colvin RB. 1990. Prolonged survival of nonhuman primate renal allograft recipients treated only with anti-CD4 monoclonal antibody. Surgery 108: 406-413.

Dehoux JP, Talpe S, Dewolf N, Otsuka M, Oike F, Jamar F, de la Parra B, Latinne D, Bazin H, Gianello P. 2000. Effects on human and nonhuman primate immune response of a 
D.J. Anderson and A.D. Kirk

new rat anti-CD2 monoclonal antibody. Transplantation 69: $2622-2633$.

de Vos AF, Melief MJ, van Riel D, Boon L, van Eijk M, de Boer M, Laman JD. 2004. Antagonist anti-human CD40 antibody inhibits germinal center formation in cynomolgus monkeys. Eur J Immunol 34: 3446-3455.

Elster EA, Xu H, Tadaki DK, Burkly LC, Berning JD, Baumgartner RE, Cruzata F, Patterson NB, Harlan DM, Kirk AD. 2001a. Primate skin allotransplantation with antiCD154 monotherapy. Transplant Proc 33: 675-676.

Elster EA, Xu H, Tadaki DK, Montgomery S, Burkly LC, Berning JD, Baumgartner RE, Cruzata F, Marx R, Harlan DM, et al. 2001b. Treatment with the humanized CD154specific monoclonal antibody, hu5C8, prevents acute rejection of primary skin allografts in nonhuman primates. Transplantation 72: 1473-1478.

Findlay L, Eastwood D, Stebbings R, Sharp G, Mistry Y, Ball C, Hood J, Thorpe R, Poole S. 2010. Improved in vitro methods to predict the in vivo toxicity in man of therapeutic monoclonal antibodies including TGN1412. J Immunol Methods 352: 1-12.

Ford ML, Larsen CP. 2009. Translating costimulation blockade to the clinic: Lessons learned from three pathways. Immunol Rev 229: 294-306.

Ford ML, Koehn BH, Wagener ME, Jiang W, Gangappa S, Pearson TC, Larsen CP. 2007. Antigen-specific precursor frequency impacts $\mathrm{T}$ cell proliferation, differentiation, and requirement for costimulation. J Exp Med 204: 299-309.

Germain RN. 2001. The art of the probable: System control in the adaptive immune system. Science 293: 240-245.

Haanstra KG, Sick EA, Ringers J, Wubben JAM, Kuhn EM,'t Hart BA, Boon L, Jonker M. 2006. No synergy between ATG induction and costimulation blockade induced kidney allograft survival in rhesus monkeys. Transplantation 82: 1194-1201.

Hamann A, Jablonski-Westrich D, Duijvestijn A, Butcher EC, Baisch H, Harder R, Thiele HG. 1988. Evidence for an accessory role of LFA-1 in lymphocyte-high endothelium interaction during homing. J Immunol 140: 693699.

Hammer C, Thein E. 2002. Visualization of the effect of polyclonal antithymocyte globulins on adhesion of leukocytes. Transplant Proc 34: 2486-2487.

Hausen B, Gummert J, Berry GJ, Christians U, Serkova N, Ikonen T, Hook L, Legay F, Schuler W, Schreier MH, et al. 2000a. Prevention of acute allograft rejection in nonhuman primate lung transplant recipients: Induction with chimeric anti-interleukin-2 receptor monoclonal antibody improves the tolerability and potentiates the immunosuppressive activity of a regimen using low doses of both microemulsion cyclosporine and 40-O-(2-hydroxyethyl)-rapamycin. Transplantation 69: 488-496.

Hausen B, Ikonen T, Briffa N, Berry GJ, Christians U, Robbins RC, Hook L, Serkova N, Benet LZ, Schuler W, et al. 2000b. Combined immunosuppression with cyclosporine (neoral) and SDZ RAD in non-human primate lung transplantation: Systematic pharmacokinetic-based trials to improve efficacy and tolerability. Transplantation 69: 76-86.

Hausen B, Klupp J, Christians U, Higgins JP, Baumgartner RE, Hook LE, Friedrich S, Celnicker A, Morris RE. 2001.
Coadministration of either cyclosporine or steroids with humanized monoclonal antibodies against CD80 and CD86 successfully prolong allograft survival after life supporting renal transplantation in cynomolgus monkeys. Transplantation 72: 1128-1137.

Helg C, Chapuis B, Bolle JF, Morel P, Salomon D, Roux E, Antonioli V, Jeannet M, Leski M. 1994. Renal transplantation without immunosuppression in a host with tolerance induced by allogeneic bone marrow transplantation. Transplantation 58: 1420-1422.

Hering BJ, Walawalkar N. 2009. Pig-to-nonhuman primate islet xenotransplantation. Transpl Immunol 21: 81-86.

Hirshberg B, Preston EH, Xu H, Tal MG, Neeman Z, Bunnell D, Soleimanpour S, Hale DA, Kirk AD, Harlan DM. 2003. Rabbit antithymocyte globulin induction and sirolimus monotherapy supports prolonged islet allograft function in a nonhuman primate islet transplantation model. Transplantation 76: 55-60.

Hovius SE, Stevens HP, Van Nierop PW, Godschalk M, Kusuma A, Deelen G, Van de Bergh M, Van der Meulen JC. 1992. Replantation of the radial side of the hand in the rhesus monkey: Anatomical and functional aspects. A preliminary study to composite tissue allografting. $J$ Hand Surg Br 17: 651-656.

Imai A, Suzuki T, Sugitani A, Itoh T, Ueki S, Aoyagi T, Yamashita K, Taniguchi M, Takahashi N, Miura T, et al. 2007. A novel fully human anti-CD40 monoclonal antibody, 4D11, for kidney transplantation in cynomolgus monkeys. Transplantation 84: 1020-1028.

Jacobsen N, Taaning E, Ladefoged J, Kristensen JK, Pedersen FK. 1994. Tolerance to an HLA-B,DR disparate kidney allograft after bone-marrow transplantation from same donor. Lancet 343: 800.

Jonker M, van de Hout Y, Neuhaus P, Ringers J, Kuhn EM, Bruijn JA, Noort R, Doxiadis G, Otting N, Bontrop RE, et al. 1998. Complete withdrawal of immunosuppression in kidney allograft recipients: A prospective study in rhesus monkeys. Transplantation 66: 925-927.

Jonker M, Ringers J, Ossevoort MA, Slingerland W, van den Hout Y, Haanstra K, Wubben J, Kuhn E, Friend P, Calne R. 2002. Long-term kidney graft survival by delayed T cell ablative treatment in rhesus monkeys. Transplantation 73: 874-880.

Kanmaz T, Fechner JJH, Torrealba J, Kim HT, Dong Y, Oberley TD, Schultz JM, Bloom DD, Katayama M, Dar W, et al. 2004. Monotherapy with the novel human anti-CD154 monoclonal antibody ABI793 in rhesus monkey renal transplantation model. Transplantation 77: 914-920.

Kaplon RJ, Hochman PS, Michler RE, Kwiatkowski PA, Edwards NM, Berger CL, Xu H, Meier W, Wallner BP, Chisholm P, et al. 1996. Short course single agent therapy with an LFA-3-IgG1 fusion protein prolongs primate cardiac allograft survival. Transplantation 61: 356-363.

Kavanaugh AF, Lightfoot E, Lipsky PE, OppenheimerMarks N. 1991. Role of CD11/CD18 in adhesion and transendothelial migration of T cells. Analysis utilizing CD18-deficient T cell clones. J Immunol 146: 4149-4156.

Kawai T, Cosimi AB, Colvin RB, Powelson J, Eason J, Kozlowski T, Sykes M, Monroy R, Tanaka M, Sachs DH. 1995. Mixed allogeneic chimerism and renal allograft tolerance in cynomolgus monkeys. Transplantation 59: 256-262. 
Kawai T, Poncelet A, Sachs DH, Mauiyyedi S, Boskovic S, Wee SL, Ko DS, Bartholomew A, Kimikawa M, Hong HZ, et al. 1999. Long-term outcome and alloantibody production in a non-myeloablative regimen for induction of renal allograft tolerance. Transplantation 68: 1767-1775.

Kawai T, Andrews D, Colvin R, Sachs D, Cosimi A. 2000. Thromboembolic complications after treatment with monoclonal antibody against CD40 ligand. Nat Med 6: 114.

Kawai T, Cosimi AB, Wee SL, Houser S, Andrews D, Sogawa H, Phelan J, Boskovic S, Nadazdin O, Abrahamian G, et al. 2002. Effect of mixed hematopoietic chimerism on cardiac allograft survival in cynomolgus monkeys. Transplantation 73: 1757-1764.

Kawai T, Sogawa H, Boskovic S, Abrahamian G, Smith RN, Wee SL, Andrews D, Nadazdin O, Koyama I, Sykes M, et al. 2004. CD154 blockade for induction of mixed chimerism and prolonged renal allograft survival in nonhuman primates. Am J Transplant 4: 1391-1398.

Kawai T, Cosimi AB, Spitzer TR, Tolkoff-Rubin N, Suthanthiran M, Saidman SL, Shaffer J, Preffer FI, Ding R, Sharma V, et al. 2008. HLA-mismatched renal transplantation without maintenance immunosuppression. N Engl J Med 358: 353-361

Kayler L, Kang D, Molmenti E, Howard R. 2010. Kidney transplant ureteroneocystostomy techniques and complications: Review of the literature. Transplant Proc 42: $1413-1420$.

Kean LS, Adams AB, Strobert E, Hendrix R, Gangappa S, Jones TR, Shirasugi N, Ridby MR, Hamby K, Jian J, et al. 2007. Induction of chimerism in rhesus macaques through stem cell transplant and costimulation blockadebased immunosuppression. Am J Transplant 7: 320-335.

Kean LS, Singh K, Blazar BR, Larsen CP. 2012. Nonhuman primate transplant models finally evolve: Detailed immunogenetic analysis creates new models and strengthens the old. Am J Transplant 12: 812-819.

Kelishadi SS, Azimzadeh AM, Zhang T, Stoddard T, Welty E, Avon C, Higuchi M, Laaris A, Cheng XF, McMahon C, et al. 2010. Preemptive $\mathrm{CD} 20^{+} \mathrm{B}$ cell depletion attenuates cardiac allograft vasculopathy in cyclosporine-treated monkeys. J Clin Invest 120: 1275.

Kenyon NS, Fernandez LA, Lehmann R, Masetti M, Ranuncoli A, Chatzipetrou M, Iaria G, Han D, Wagner JL, Ruiz $\mathrm{P}$, et al. 1999a. Long-term survival and function of intrahepatic islet allografts in baboons treated with humanized anti-CD154. Diabetes 48: 1473-1481.

Kenyon NS, Chatzipetrou M, Masetti M, Ranuncoli A, Oliveira $\mathrm{M}$, Wagner JL, Kirk AD, Harlan DM, Burkly LC, Ricordi C. 1999b. Long-term survival and function of intrahepatic islet allografts in rhesus monkeys treated with humanized anti-CD154. Proc Natl Acad Sci 96: 8132-8137.

Kim GB, Wang Z, Liu YY, Stavrou S, Mathias A, Goodwin KJ, Thomas JM, Neville DM. 2007. A fold-back singlechain diabody format enhances the bioactivity of an antimonkey CD3 recombinant diphtheria toxin-based immunotoxin. Protein Eng Des Sel 20: 425-432.

Kimikawa M, Sachs DH, Colvin RB, Bartholomew A, Kawai T, Cosimi AB. 1997. Modifications of the conditioning regimen for achieving mixed chimerism and donor-spe- cific tolerance in cynomolgus monkeys. Transplantation 64: 709-716.

Kirk AD. 1999. Transplantation tolerance: A look at the nonhuman primate literature in the light of modern tolerance theories. Crit Rev Immunol 19: 349-388.

Kirk AD. 2003. Crossing the bridge: Large animal models in translational transplantation research. Immunol Rev 196: $176-196$.

Kirk AD, Harlan DM, Armstrong NN, Davis TA, Dong Y, Gray GS, Hong X, Thomas D, Fechner JH Jr, Knechtle SJ. 1997. CTLA4-Ig and anti-CD40 ligand prevent renal allograft rejection in primates. Proc Natl Acad Sci 94: 8789-8794.

Kirk AD, Burkly LC, Batty DS, Baumgartner RE, Berning JD, Buchanan K, Fechner JH Jr, Germond RL, Kampen RL, Patterson NB, et al. 1999. Treatment with humanized monoclonal antibody against $\mathrm{CD} 154$ prevents acute renal allograft rejection in nonhuman primates. Nat Med 5: 686-693.

Kirk AD, Tadaki DK, Celniker A, Batty DS, Berning JD, Colonna JO, Cruzata F, Elster EA, Gray GS, Kampen RL, et al. 2001. Induction therapy with monoclonal antibodies specific for CD80 and CD86 delays the onset of acute renal allograft rejection in non-human primates. Transplantation 72: 377-384.

Knechtle SJ, Vargo D, Fechner J, Zhai Y, Wang J, Hanaway MJ, Scharff J, Hu H, Knapp L, Watkins D, et al. 1997. FN18-CRM9 immunotoxin promotes tolerance in primate renal allografts. Transplantation 63: 1-6.

Knechtle SJ, Fechner JH, Dong YC, Stavrou S, Neville DM, Oberley T, Buckley P, Armstrong N, Rusterholz K, Hong $\mathrm{X}$, et al. 1998a. Primate renal transplants using immunotoxin. Surgery 124: 438-446.

Knechtle SJ, Fechner JH, Stavrou S, Neville DM, Dong Y, Hong X, Tsuchida M, Hamawy MM. 1998b. Reversal of acute allograft rejection using immunotoxin. Transplant Proc 30: 2150-2151.

Kolber-Simonds D, Lai L, Watt SR, Denaro M, Arn S, Augenstein ML, Betthauser J, Carter DB, Greenstein JL, Hao Y, et al. 2004. Production of $\alpha$-1,3-galactosyltransferase null pigs by means of nuclear transfer with fibroblasts bearing loss of heterozygosity mutations. Proc Natl Acad Sci 101: 7335-7340.

Krieger NR, Yuh D, McIntyre WB, Flavin TF, Yin D, Robbins R, Fathman CG. 1998. Prolongation of cardiac graft survival with anti-CD4Ig plus hCTLA4Ig in primates. J Surg Res 76: 174-178.

Lai L, Kolber-Simonds D, Park KW, Cheong HT, Greenstein JL, Im GS, Samuel M, Bonk A, Rieke A, Day BN, et al. 2002. Production of $\alpha$-1,3-galactosyltransferase knockout pigs by nuclear transfer cloning. Science 295: 10891092.

Larsen CP, Elwood ET, Alexander DZ, Ritchie SC, Hendrix R, Tucker-Burden C, Cho HR, Aruffo A, Hollenbaugh D, Linsley PS, et al. 1996. Long-term acceptance of skin and cardiac allografts after blocking CD40 and CD28 pathways. Nature 381: 434-438.

Larsen CP, Pearson TC, Adams AB, Tso P, Shirasugi N, Strobert E, Anderson D, Cowan S, Price K, Naemura J, et al. 2005. Rational development of LEA29Y (belatacept), a high-affinity variant of CTLA4-Ig with potent immunosuppressive properties. Am J Transplant 5: 443-453. 
D.J. Anderson and A.D. Kirk

Larsen CP, Page A, Linzie KH, Russell M, Deane T, Stempora L, Strobert E, Penedo MC, Ward T, Wiseman R, et al. 2010. An MHC-defined primate model reveals significant rejection of bone marrow after mixed chimerism induction despite full MHC matching. Am J Transplant 10: 2396-2409.

Levisetti MG, Padrid PA, Szot GL, Mittal N, Meehan SM, Wardrip CL, Gray GS, Bruce DS, Thistlethwaite JR Jr, Bluestone JA. 1997. Immunosuppressive effects of human CTLA4Ig in a non-human primate model of allogeneic pancreatic islet transplantation. J Immunol 159: $5187-5191$.

Li J, Chen G, Ye P, Wang S, Zhang K, Chen W, Stepkowski SM, Li J, Zhong S, Xia J. 2011. CCR5 blockade in combination with cyclosporine increased cardiac graft survival and generated alternatively activated macrophages in primates. J Immunol 186: 3753-3761.

Liu C, Noorchashm H, Sutter JA, Naji M, Prak EL, Boyer J, Green T, Rickels MR, Tomaszewski JE, Koeberlein B, et al. 2007. B lymphocyte-directed immunotherapy promotes long-term islet allograft survival in nonhuman primates. Nat Med 13: 1295-1298.

Lo DJ, Anderson DJ, Weaver TA, Leopardi F, Song M, Farris AB, Strobert EA, Jenkins J, Turgeon NA, Mehta AK, et al. 2013. Belatacept and sirolimus prolong nonhuman primate renal allograft survival without a requirement for memory T cell depletion. Am J Transplant 13: 320-328.

London CA, Lodge MP, Abbas AK. 2000. Functional responses and costimulator dependence of memory $\mathrm{CD}^{+}$T cells. J Immunol 164: 265-272.

Lowe M, Badell IR, Thompson P, Martin B, Leopardi F, Strobert E, Price AA, Abdulkerim HS, Wang R, Iwakoshi NN, et al. 2012. A novel monoclonal antibody to CD40 prolongs islet allograft survival. Am J Transplant 12: 2079-2087.

Lowe MC, Badell IR, Turner AP, Thompson PW, Leopardi FV, Strobert EA, Larsen CP, Kirk AD. 2013. Belatacept and sirolimus prolong nonhuman primate islet allograft survival: Adverse consequences of concomitant alefacept therapy. Am J Transplant 13: 312-319.

Ma SL, Hu HZ, Thompson J, Stavrou S, Scharff J, Neville DM. 1997. Genetic construction and characterization of an anti-monkey CD3 single-chain immunotoxin with a truncated diphtheria toxin. Bioconjug Chem 8: 695-701.

Ma A, Qi S, Song L, Hu Y, Dun H, Massicotte E, Dupuis M, Daloze P, Chen H. 2011. Adoptive transfer of $\mathrm{CD}^{+}$ $\mathrm{CD}_{25}{ }^{+}$regulatory cells combined with low-dose sirolimus and anti-thymocyte globulin delays acute rejection of renal allografts in Cynomolgus monkeys. Int Immunopharmacol 11: 618-629.

Mezrich JD, Haller GW, Arn JS, Houser SL, Madsen JC, Sachs DH. 2003. Histocompatible miniature swine: An inbred large-animal model. Transplantation 75: 904907.

Montgomery SP, Mog SR, Xu H, Tadaki DK, Hirshberg B, Berning JD, Leconte J, Harlan DM, Hale D, Kirk AD. 2002a. Efficacy and toxicity of a protocol using sirolimus, tacrolimus and daclizumab in a nonhuman primate renal allotransplant model. Am J Transplant 2: 381-385.

Montgomery SP, Xu H, Tadaki DK, Celniker A, Burkly LC, Berning JD, Cruzata F, Elster EA, Gray G, Kampen RL, et al. 2002b. Combination induction therapy with mono- clonal antibodies specific for CD80, CD86, and CD154 in nonhuman primate renal transplantation. Transplantation 74: $1365-1369$.

Mourad GJ, Preffer FI, Wee SL, Powelson JA, Kawai T, Delmonico FL, Knowles RW, Cosimi AB, Colvin RB. 1998. Humanized IgG1 and IgG4 anti-CD4 monoclonal antibodies: Effects on lymphocytes in the blood, lymph nodes, and renal allografts in cynomolgus monkeys. Transplantation 65: 632-641.

Moy VT, Brian AA. 1992. Signaling by lymphocyte functionassociated antigen 1 (LFA-1) in B cells: Enhanced antigen presentation after stimulation through LFA-1. J Exp Med 175: $1-7$.

Myburgh JA, Smit JA, Pieterz GA, Ling S, Sandrin MS, McKenzie IFC. 2001. Tolerance in baboon kidney transplantation with total lymphoid irradiation (TLI) and anti-CD3/CD4-Idarubicin conjugates. Transplantation 72: $1150-1152$.

Nam KH, Akari H, Terao K, Ohto H, Itagaki S, Yoshikawa Y. 1998a. Age-dependent remodeling of peripheral blood $\mathrm{CD}^{+} \mathrm{CD}^{+} \mathrm{T}$ lymphocytes in cynomolgus monkeys. Dev Comp Immunol 22: 239-248.

Nam KH, Akari H, Terao K, Itagaki S, Yoshikawa Y. 1998b. Age-related changes in major lymphocyte subsets in cynomolgus monkeys. Exp Anim 47: 159-166.

National Research Council. 2011. Guide for the care and use of laboratory animals, 8th ed. The National Academies Press, Washington, DC.

Neville DM, Scharff J, Hu HZ, Rigaut K, Shiloach J, Slingerland W, Jonker M. 1996. A new reagent for the induction of T-cell depletion, anti-CD3-CRM9. J Immunother 19: $85-92$.

Nicolls MR, Gill RG. 2006. LFA-1 (CD11a) as a therapeutic target. Am J Transplant 6: 27-36.

Nottle MB, Beebe LFS, Harrison SJ, Mcllfatrick SM, Ashman RJ, O'Connell PJ, Salvaris EJ, Fisicaro N, Pommey S, Cowan PJ, et al. 2007. Production of homozygous $\alpha$ 1,3-galactosyltransferase knockout pigs by breeding and somatic cell nuclear transfer. Xenotransplantation 14: 339-344.

Ossevoort MA, de Boer M, Lorre K, Van de Voorde A, Jonker M. 1998a. Blocking of costimulatory pathways using monoclonal antibodies as a new strategy to prevent transplant rejection in a non-human primate model. Transplant Proc 30: 1061-1062.

Ossevoort MA, Ringers J, Boon L, Lorre K, van den Hout Y, Kuhn EM, de Boer M, Jonker M, de Waele P. 1998b. Blocking of costimulation prevents kidney graft rejection in rhesus monkeys. Transplant Proc 30: 2165-2166.

Otting N, Heijmans CMC, Noort RC, de Groot NG, Doxiadis GGM, van Rood JJ, Watkins DI, Bontrop RE. 2005. Unparalleled complexity of the MHC class I region in rhesus macaques. Proc Natl Acad Sci 102: 1626-1631.

Owen RD. 1945. Immunogenetic consequences of vascular anastomoses between bovine twins. Science 102: 400401.

Page A, Srinivasan S, Singh K, Russell M, Hamby K, Deane T, Sen S, Stemora L, Leopardi F, Price AA, et al. 2012a. CD40 blockade combines with CTLA4Ig and sirolimus to produce mixed chimerism in an MHC-defined rhesus macaque transplant model. Am J Transplant 12: 115-125. 
Page EK, Page AJ, Kwun J, Gibby AC, Leopardi F, Jenkins JB, Strobert EA, Song M, Hennigar RA, Iwakoshi N, et al. 2012b. Enhanced de novo alloantibody and antibodymediated injury in rhesus macaques. Am J Transplant 12: 2395-2405.

Pearl JP, Xu H, Leopardi F, Preston E, Kirk AD. 2007. CD154 blockade, sirolimus, and donor-specific transfusion prevents renal allograft rejection in cynomolgus monkeys despite homeostatic T-cell activation. Transplantation 83: $1219-1225$.

Pearson TC, Alexander DZ, Winn KJ, Linsley PS, Lowry RP, Larsen CP. 1994. Transplantation tolerance induced by CTLA4-Ig. Transplantation 57: 1701-1706.

Pearson TC, Trambley J, Odom K, Anderson DC, Cowan SR, Bray R, Lin A, Hollenbaugh D, Aruffo A, Siadak AW, et al. 2002. Anti-CD40 therapy extends renal allograft survival in rhesus macaques. Transplantation 74: 933-940.

Penedo MCT, Bontrop RE, Heijmans CMC, Otting N, Noort R, Rouweler AJ, de Groot N, de Groot NG, Ward T, Doxiadis GG. 2005. Microsatellite typing of the rhesus macaque MHC region. Immunogenetics 57: 198-209.

Pescovitz MD, Thistlethwaite JR, Auchincloss H, Ildstad ST, Sharp TG, Terrill R, Sachs DH. 1984. Effect of class II antigen matching on renal allograft survival in miniature swine. J Exp Med 160: 1495-1508.

Pfeiffer S, Iii GLZ, Azimzadeh AM, Atkinson J, Newman R, Pierson RN. 2001. Monotherapy with anti-CD40 ligand antibody (IDEC 131) for non-human primate allograft heart transplantation. J Heart Lung Transplant 20: 250.

Phelps CJ, Koike C, Vaught TD, Boone J, Wells KD, Chen SH, Ball S, Specht SM, Polejaeva IA, Monahan JA, et al. 2003. Production of $\alpha 1,3$-galactosyltransferase-deficient pigs. Science 299: 411-414.

Pierson RN III, Chang AC, Blum MG, Blair KS, Scott MA, Atkinson JB, Collins BJ, Zhang JP, Thomas DW, Burkly LC, et al. 1999. Prolongation of primate cardiac allograft survival by treatment with ANTI-CD40 ligand (CD154) antibody. Transplantation 68: 1800-1805.

Pierson RN, Crowe JE, Pfeiffer S, Atkinson J, Azimzadeh A, Miller GG. 2001. CD40-ligand in primate cardiac allograft and viral immunity. Immunol Res 23: 253-262.

Pilat N, Sayegh MH, Wekerle T. 2011. Costimulatory pathways in transplantation. Semin Immunol 23: 293-303.

Poirier N, Azimzadeh AM, zhang T, Dilek N, Mary C, Nguyen B, Tillou X, Wu G, Reneaudin K, Hervouet J, et al. 2010. Inducing CTLA-4-dependent immune regulation by selective $\mathrm{CD} 28$ blockade promotes regulatory $\mathrm{T}$ cells in organ transplantation. Sci Transl Med 2: p17ra10.

Poirier N, Mary C, Dilek N, Hervouet J, Minault D, Blancho G, Vanhove B. 2012. Preclinical efficacy and immunological safety of FR104, an antagonist anti-CD28 monovalent Fab' antibody. Am J Transplant 12: 2630-2640.

Politano VA, Leadbetter WF. 1958. An operative technique for the correction of vesicoureteral reflux. J Urol 79: 932941.

Poston RS, Robbins RC, Chan B, Simms P, Presta L, Jardieu P, Morris RE. 2000. Effects of humanized monoclonal antibody to rhesus CD11a in rhesus monkey cardiac allograft recipients. Transplantation 69: 2005-2013.

Preston EH, Xu H, Dhanireddy KK, Pearl JP, Leopardi FV, Starost MF, Hale DA, Kirk AD. 2005. IDEC-131 (anti-
CD154), sirolimus and donor-specific transfusion facilitate operational tolerance in non-human primates. $A m$ J Transplant 5: 1032-1041.

Préville X, Flacher M, LeMauff B, Beauchard S, Davelu P, Tiollier J, Revillard JP. 2001. Mechanisms involved in antithymocyte globulin immunosuppressive activity in a nonhuman primate model. Transplantation 71: 460468.

Pribila JT, Quale AC, Mueller KL, Shimizu Y. 2004. Integrins and T cell-mediated immunity. Аnпu Rev Immunol 22: 157-180.

Qi S, Xu D, Peng J, Vu MD, Wu J, Bekersky I, Fitzsimmons WE, Peets J, Sehgal S, Daloze P, et al. 2000. Effect of tacrolimus (FK506) and sirolimus (rapamycin) monoand combination therapy in prolongation of renal allograft survival in the monkey. Transplantation 69: 12751283.

Rao P, Jiang H, Wang F. 2000. Cloning of the rhesus lymphocryptovirus viral capsid antigen and Epstein-Barr virus-encoded small RNA homologues and use in diagnosis of acute and persistent infections. J Clin Microbiol 38: 3219-3225.

Reemtsma K. 1969. Heterotransplantation. Transplant Proc 1: 251-255.

Rivailler P, Carville A, Kaur A, Rao P, Quink C, Kutok JL, Westmoreland S, Klumpp S, Simon A, Aster JC, et al. 2004. Experimental rhesus lymphocryptovirus infection in immunosuppressed macaques: An animal model for Epstein-Barr virus pathogenesis in the immunosuppressed host. Blood 104: 1482-1489.

Rodriguez-Carreno MP, Lopez-Fuertes L, Revilla C, Ezquerra A, Alonso F, Dominguez J. 2002. Phenotypic characterization of porcine IFN- $\boldsymbol{\gamma}$-producing lymphocytes by flow cytometry. J Immunol Methods 259: 171-179.

Saalmüller A, Werner T, Fachinger V. 2002. T-helper cells from naive to committed. Vet Immunol Immunopathol 87: 137-145.

Sachs DH. 1992. MHC homozygous miniature swine. In Swine as models in biomedical research (ed. Swindle MM, Moody DC, Phillips LD), pp. 3-15. Iowa State University Press, Ames, Iowa.

Sachs DH. 2003. Tolerance: Of mice and men. J Clin Invest 111: 1819-1821.

Sayegh MH, Fine NA, Smith JL, Rennke HG, Milford EL, Tilney NL. 1991. Immunologic tolerance to renal allografts after bone marrow transplants from the same donors. Ann Intern Med 114: 954-955.

Schmidtko J, Wang R, Wu CL, Mauiyyedi S, Harris NL, Pelle Della P, Brousaides N, Zagachin L, Ferry JA, Wang F, et al. 2002. Posttransplant lymphoproliferative disorder associated with an Epstein-Barr-related virus in cynomolgus monkeys. Transplantation 73: 1431-1439.

Schuler W, Bigaud M, Brinkmann V, Di Padova F, Geisse S, Gram H, Hungerford V, Kleuser B, Kristofic C, Menninger K, et al. 2004. Efficacy and safety of ABI793, a novel human anti-human CD154 monoclonal antibody, in cynomolgus monkey renal allotransplantation. Transplantation 77: 717-726.

Schuurman HJ, Menninger K, Audet M, Kunkler A, Maurer C, Vedrine C, Bernhard M, Gaschen L, Brinkmann V, Quesniaux V. 2002. Oral efficacy of the new immunomodulator FTY720 in cynomolgus monkey kidney allo- 
D.J. Anderson and A.D. Kirk

transplantation, given alone or in combination with cyclosporine or RAD. Transplantation 74: 951-960.

Silverman RP, Banks ND, Detolla LJ, Shipley ST, Panda A, Sanchez RA, Azimzadeh AM, Pierson RN III, Wang D, Rodriguez ED, et al. 2008. A heterotopic primate model for facial composite tissue transplantation. Ann Plast Surg 60: 209-216.

Song L, Qi S, Dun H, Hu Y, Ma A, Yu G, Xiong Z, Zhu S, Wang X, Xu D, et al. 2010. Surgical complications in kidney transplantation in nonhuman primates. Microsurgery 30: 327-331.

Stark GB, Swartz WM, Narayanan K, Møller AR. 1987. Hand transplantation in baboons. Transplant Proc 19: 3968-3971.

Starzl TE, Demetris AJ, Trucco M, Ramos H, Zeevi A, Rudert WA, Kocova M, Ricordi C, Iistad S, Murase N. 1992. Systemic chimerism in human female recipients of male livers. Lancet 340: 876-877.

Stebbings R, Findlay L, Edwards C, Eastwood D, Bird C, North D, Mistry Y, Dilger P, Liefooghe E, Cludts I, et al. 2007. "Cytokine storm" in the phase I trial of monoclonal antibody TGN1412: Better understanding the causes to improve preclinical testing of immunotherapeutics. J Immunol 179: 3325-3331.

Suntharalingam G, Perry MR, Ward S, Brett SJ, CastelloCortes A, Brunner MD, Panoskaltsis N. 2006. Cytokine storm in a phase 1 trial of the anti-CD28 monoclonal antibody TGN1412. N Engl J Med 7: 1018-1028.

Sykes M. 2001. Mixed chimerism and transplant tolerance. Immunity 14: 417-424.

't Hart BA, Amor S, Jonker M. 2004. Evaluating the validity of animal models for research into therapies for immunebased disorders. Drug Discov Today 9: 517-524.

Thomas JM, Williams EA, Thomas FT, Millington GM. 1978. T cell-specific activity in rabbit anti-human thymocyte globulin. Correlation with immunosuppresive activity in nonhuman primates. Transplantation 25: 97102.

Thompson P, Badell IR, Lowe M, Cano J, Song M, Leopardi F, Avila J, Ruhil R, Strobert E, Korbutt G, et al. 2011. Islet xenotransplantation using gal-deficient neonatal donors improves engraftment and function. Am J Transplant 11: 2593-2602.

Todo S, Ueda Y, Demetris JA, Imventarza O, Nalesnik M, Venkataramanan R, Makowka L, Starzl TE. 1988. Immunosuppression of canine, monkey, and baboon allografts by FK 506: With special reference to synergism with other drugs and to tolerance induction. Surgery 104: 239-249.

Torrealba JR, Fernandez LA, Kanmaz T, Oberley TD, Schultz JM, Brunner KG, Peters D, Fechner JH Jr, Dong Y, Hu H, et al. 2003. Immunotoxin-treated rhesus monkeys: A model for renal allograft chronic rejection. Transplantation 76: 524-530.

Turgeon NA, Avila JG, Cano JA, Hutchinson JJ, Badell IR, Page AJ, Adams AB, Sears MH, Bowen PH, Kirk AD, et al. 2010. Experience with a novel efalizumab-based immunosuppressive regimen to facilitate single donor islet cell transplantation. Am J Transplant 10: 2082-2091.

Turka LA, Linsley PS, Lin H, Brady W, Leiden JM, Wei RQ, Gibson ML, Zheng XG, Myrdal S, Gordon D, et al. 1992. T-cell activation by the CD28 ligand B7 is required for cardiac allograft rejection in vivo. Proc Natl Acad Sci 89: 11102-11105.

Van Seventer GA, Shimizu Y, Horgan KJ, Shaw S. 1990. The LFA-1 ligand ICAM-1 provides an important costimulatory signal for $\mathrm{T}$ cell receptor-mediated activation of resting T cells. J Immunol 144: 4579-4586.

Vincenti F, Mendez R, Pescovitz M, Rajagopalan PR, Wilkinson AH, Butt K, Laskow D, Slakey DP, Lorder MI, Garg JP, et al. 2007. A phase I/II randomized openlabel multicenter trial of efalizumab, a humanized antiCD11a, anti-LFA-1 in renal transplantation. Am J Transplant 7: 1770-1777.

Viola A, Lanzavecchia A. 1996. T cell activation determined by $\mathrm{T}$ cell receptor number and tunable thresholds. Science 273: 104-106.

Warnock RA, Askari S, Butcher EC, Andrian von UH. 1998. Molecular mechanisms of lymphocyte homing to peripheral lymph nodes. J Exp Med 187: 205-216.

Weaver TA, Charafeddine AH, Agarwal A, Turner AP, Russell M, Leopardi FV, Kampen RL, Stempora L, Song M, Larsen CP, et al. 2009. Alefacept promotes co-stimulation blockade based allograft survival in nonhuman primates. Nat Med 15: 746-749.

Wee SL, Stroka DM, Preffer FI, Jolliffe LK, Colvin RB, Cosimi AB. 1992. The effects of OKT4A monoclonal antibody on cellular immunity of nonhuman primate renal allograft recipients. Transplantation 53: 501-507.

Wijkstrom M, Kenyon NS, Kirchhof N, Kenyon NM, Mullon C, Lake P, Cottens S, Ricordi C, Hering BJ. 2004. Islet allograft survival in nonhuman primates immunosuppressed with basiliximab, RAD, and FTY720. Transplantation 77: 827-835.

Williams MA, Trambley J, Ha J, Adams AB, Durham MM, Rees P, Cowan SR, Pearson TC, Larsen CP. 2000. Genetic characterization of strain differences in the ability to mediate CD40/CD28-independent rejection of skin allografts. J Immunol 165: 6849-6857.

Wiseman RW, Karl JA, Bimber BN, O'Leary CE, Lank SM, Tuscher JJ, Detmer AM, Bouffard P, Levenkova N, Turcotte CL, et al. 2009. Major histocompatibility complex genotyping with massively parallel pyrosequencing. Nat Med 15: 1322-1326.

Wood K, Sachs DH. 1996. Chimerism and transplantation tolerance: Cause and effect. Immunol Today 17: 584-587.

Xu H, Elster E, Batty D, Berning J, Burkly L, Kampen R, Swanson S, Tadaki D, Harlan D, Kirk A. 2001. Effects of dose and duration of anti-CD154 antibody therapy in preventing renal allograft rejection in a nonhuman primate model. Transplant Proc 33: 223-224.

Xu H, Montgomery SP, Preston EH, Tadaki DK, Hale DA, Harlan DM, Kirk AD. 2003. Studies investigating pretransplant donor-specific blood transfusion, rapamycin, and the CD154-specific antibody IDEC-131 in a nonhuman primate model of skin allotransplantation. J Immunol 170: 2776-2782.

Xu H, Zhang X, Mannon RB, Kirk AD. 2006. Platelet-derived or soluble CD154 induces vascularized allograft rejection independent of cell-bound CD154. J Clin Invest 116: 769-774.

Yue Y, Barry PA. 2008. Rhesus cytomegalovirus a nonhuman primate model for the study of human cytomegalovirus. Adv Virus Res 72: 207-226. 


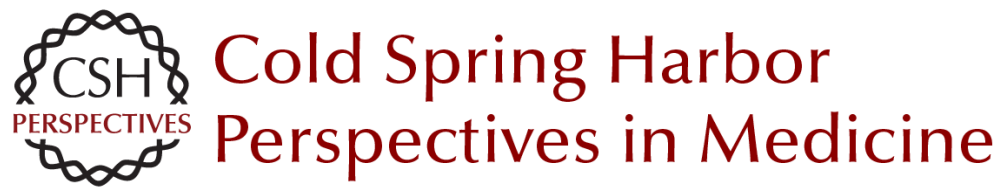

\section{Primate Models in Organ Transplantation}

Douglas J. Anderson and Allan D. Kirk

Cold Spring Harb Perspect Med 2013; doi: 10.1101/cshperspect.a015503

Subject Collection Transplantation

Heart Transplantation: Challenges Facing the Field

Makoto Tonsho, Sebastian Michel, Zain Ahmed, et al.

Bioethics of Organ Transplantation Arthur Caplan

Overview of Clinical Lung Transplantation Jonathan C. Yeung and Shaf Keshavjee

Immunological Challenges and Therapies in

Xenotransplantation Marta Vadori and Emanuele Cozzi

Clinical Aspects: Focusing on Key Unique Organ-Specific Issues of Renal Transplantation Sindhu Chandran and Flavio Vincenti

T-Cell Costimulatory Blockade in Organ

Transplantation Jonathan S. Maltzman and Laurence A. Turka

Regulatory T-Cell Therapy in Transplantation: Moving to the Clinic Qizhi Tang and Jeffrey A. Bluestone

Opportunistic Infections--Coming to the Limits of Immunosuppression?

Jay A. Fishman
Overview of the Indications and Contraindications for Liver Transplantation

Stefan Farkas, Christina Hackl and Hans Jürgen Schlitt

Facial and Hand Allotransplantation Bohdan Pomahac, Ryan M. Gobble and Stefan Schneeberger

Induction of Tolerance through Mixed Chimerism David H. Sachs, Tatsuo Kawai and Megan Sykes

Pancreas Transplantation: Solid Organ and Islet Shruti Mittal, Paul Johnson and Peter Friend

Tolerance--Is It Worth It? Erik B. Finger, Terry B. Strom and Arthur J. Matas

Lessons and Limits of Mouse Models Anita S. Chong, Maria-Luisa Alegre, Michelle L. Miller, et al.

Effector Mechanisms of Rejection Aurélie Moreau, Emilie Varey, Ignacio Anegon, et al.

The Innate Immune System and Transplantation Conrad A. Farrar, Jerzy W. Kupiec-Weglinski and Steven H. Sacks

For additional articles in this collection, see http://perspectivesinmedicine.cshlp.org/cgi/collection/ 